\title{
A Review on the Serum Electrolytes and Trace Elements Role in the Pathophysiology of COVID-19
}

\author{
Mohammad Taheri $^{1}$ (D) $\cdot$ Ali Bahrami ${ }^{2,3} \cdot$ Parisa Habibi $^{4}$ (D) Fatemeh Nouri $^{3}$ (D)
}

Received: 10 August 2020 / Accepted: 2 September 2020 / Published online: 8 September 2020

(C) Springer Science+Business Media, LLC, part of Springer Nature 2020

\begin{abstract}
All the world is involved in the COVID-19 disease caused by severe acute respiratory syndrome coronavirus 2 (SARS-CoV-2). Coronavirus is a positive-sense RNA and has an envelope. There is no specific drug for this disease and treatment methods are limited. Malnutrition and electrolyte imbalance can make dysfunction in the immune system and impairment of the immune system causes increasing the risk of infection. Understanding the aspects of biological features of the virus will help the development of diagnostic tests, pharmacological therapies, and vaccines. Here, we review and discuss increasing and decreasing some trace elements and imbalance of serum and plasma electrolytes involving in COVID-19.
\end{abstract}

Keywords Covid-19 $\cdot$ Electrolytes $\cdot$ Trace elements $\cdot$ Micronutrients

\section{Introduction}

Coronavirus disease 2019 (COVID-19), also known as severe acute respiratory syndrome coronavirus 2 (SARS-CoV-2), is caused by a strain of coronavirus which is a member of the genus Betacoronavirus and has become a global health problem that affected the lives of billions of people worldwide [1]. Understanding the aspects of biological features of the virus will help the development of diagnostic tests, pharmacological therapies, and vaccines.

It has been suggested dietary management is considered a strategy to minimize the potential risk of COVID-19 infection [2]. The nutritional condition should control in COVID-19 patients, and its disorders must be managed especially in patients associated with poor outcomes, including elderly, impaired wound healing, higher rates of nosocomial infections, and all-cause mortality. When malnutrition occurred, the

Fatemeh Nouri

Fatemenouri1@gmail.com

1 Department of Medical Microbiology, Faculty of Medicine, Hamadan University of Medical Sciences, Hamadan, Iran

2 Student Research Committee, Hamadan University of Medical Sciences, Hamadan, Iran

3 Department of Pharmaceutical Biotechnology, School of Pharmacy, Hamadan University of Medical Sciences, Hamadan, Iran

4 Neurophysiology Research Center, Faculty of Medicine, Hamadan University of Medical Sciences, Hamadan, Iran immune response also is weakened [3]. Patients with insufficient nutrition status should receive nutrition as soon as possible.

Also, some pathological conditions cause loss of water and electrolytes in the body, especially in the gastrointestinal form of COVID-19 disease, which is associated with diarrhea, in which the body experiences hyponatremia and the first step in a treat is water supply and electrolyte are lost [4]. Because of anti-inflammatory and antioxidant attributes of some vitamins and nutrients, they may be beneficial for the infected patients with COVID-19 [5, 6]. Vitamins including A, B, C, D, E, and folate and trace elements including iron, zinc, magnesium, selenium, and copper have important roles in supporting the innate and adaptive immune systems [7].

The function of immune system is supported with most nutrients that have pleiotropic roles. Also, they play a role in keeping and developing physical barriers, generation and function of antimicrobial proteins, differentiation and movement and chemotaxis of innate cells, neutrophils and macrophages phagocytosis, and relief from inflammation. By dearth of nutrients, the number of lymphocytes may decrease; phagocytosis may damage; production of cytokines may change; antibody responses may decrease, and also wound healing may be weakened $[8,9]$.

\section{Method}

The bibliographic search was performed on PubMed, Scopus, and Web of Science databases on July 27, 2020. 
Search keywords including 'Calcium' OR 'Copper' OR 'Ferrous' OR 'Folate' OR 'Folic Acid' OR 'Iron' OR 'Magnesium' OR 'Potassium' OR 'Selenium' OR 'Sodium' OR 'Zinc' OR 'Minerals' OR 'Trace Elements' AND 'coronavirus 2019' OR 'COVID-19' OR 'SARS$\mathrm{CoV}-2$ ' in all fields. Any language or date restrictions were not applied. Identified studies were screened by title, abstract, and full text. The reference list of identified studies was also evaluated to increment the sensitivity and choice of most literature which we could not identify in the database. Initiate with greatest sensitivity search found the number of 325 articles on external databases, and collected by a researcher using Endnote software. Then unifying the articles from all the cited databases and bringing out duplicate articles, the two researchers separately investigated all the articles and excluded the articles that were not related to the topic and the inclusion index criteria. Afterward, several articles after reviewing titles and abstracts were excluded. The extant articles were cautiously evaluated and the relevant study was selected. The data for the studies, based on the title, examined method, sample size, etc., were evaluated. Finally, after obtain related articles and limitations of search strategy 61 articles were analyzed. During the reviewed articles in 2020, if we identified a new article, we would include it in our study.

\section{Results}

\section{Zinc}

Zinc is an important trace element that has critical roles in the body. Proliferation and function of NK cells, macrophages, neutrophils, $\mathrm{T}$ and $\mathrm{B}$ cells, and also the production of cytokines can be controlled by zinc [10]. Also, zinc can protect cells from the effect of reactive oxygen species [11]. Zinc is involved in the controls of common cold due to its inhibitory mechanism in viral replication [12] and attachment to the nasopharyngeal mucous, and there is any evidence that it decreases the duration of common cold about 1.65 days. Also, zinc alleviates gastrointestinal and lower respiratory symptoms [13]. Although it depends on age, zinc dose, and salt form. In vitro studies showed that some respiratory pathogens like rhinovirus, respiratory syncytial virus, and SARS-CoV pathogenesis were modified by zinc [14]. Development and maintenance of both innate and adaptive immune systems need zinc and its deficiency causes dysfunction in the activation, and maturation of lymphocytes, impairment in cellular communication by cytokines and reduce innate immunity [9, $15,16]$. Chloroquine (CQ) and hydroxychloroquine agents (HCQ) both stack up in endosomes, lysosomes, or Golgi vesicles and increase intracellular PH. Since the new 2019 coronavirus is acidophile, so increasing in intracellular PH might be the cause of treatment of SARS-CoV-2. It has shown that CQ is a zinc ionophore and transmits extracellular zinc into the cells [17]. Zinc has shown that it has an antiviral activity against several viruses. It has been understood that zinc inhibits the activity of RNA-dependent RNA polymerase (RdRp) of coronavirus [18]. Because of the antiviral effect of zinc and function of $\mathrm{CQ} / \mathrm{HCQ}$ as a zinc ionophore compound, co-adminstration of them for the synergistic effect seems to be useful for COVID-19 treatment [19]. Indeed increasing the intracellular $\mathrm{Zn}^{2+}$ through CQ can be against SARS-CoV-2 [20]. Pyrithione also is a zinc ionophore, so using zinc with a low amount of pyrithione inhibits the SARS coronavirus replication [6]. Some antiviral drugs can be more efficient by using zinc, and their abdominal discomfort will decrease [11]. Using a combination of CQ, zinc, and azithromycin as eye drops or spray/aerosol for eyelids and the ocular surface can prevent binding of SARS-CoV-2 to the eyes as one of the major pathways of importing the virus into the body [21]. Zinc ions in the structure of viral proteins also can be targeted, and some drugs like disulfiram have shown that it can release $\mathrm{Zn}^{2+}$ from proteins of MERS-CoV and SARS-CoV and impair the proteins. So these $\mathrm{Zn}$-ejector drugs are potential for the treatment of SARS-Cov-2 [20]. Zinc also enhances cytokines response and also causes an increase in the generation of $\mathrm{CD} 4^{+}$naive $\mathrm{T}$ cells $[22,23]$.

\section{Selenium}

Selenium in the structure of some enzymes and as well as vitamin E prohibits producing free radicals [24]. Cellular immunity gets better by using selenium in people with a low concentration of plasma selenium and also a mutation in the viral genome decreased [9]. Deficiency in selenium unmakes the immune system of the host and also causes oxidative stress that increases the risk of mutation in the viral genome and changes it to a more dangerous virus [25, 26]. It has shown that using selenium with ginseng stemleaf saponins in chickens causes the response of the immune system to a live bivalent vaccine of coronavirus $[6$, 27]. Mutation in the virus has been seen after passaging a virus in animals with selenium deficiency. All of these data lead us to assume that there is an association between selenium condition and COVID-19. It has been observed that the death rate in low selenium is higher than in other cities. It has been reported that selenium deficiency causes an increase in viral replication and mutation and also more pathogenicity and mortality [28]. It has demonstrated that high selenium intake $(50-100 \mu \mathrm{g} /$ day $)$ causes better and more immune responses in adults [29] especially cellular immune responses. Also, it has been observed that an increase in selenium intake causes more production of $\mathrm{T}$ cells and IL-8 and IL-10 cytokines [23, 30]. 


\section{Iron (Ferrous)}

Many of host cellular functions need iron like enzymatic and non-enzymatic reactions, ATP generation, RNA/DNA synthesis, and repair and survival of ferroptosis of cells. Viral replication also needs iron. Proliferation and maturation of $\mathrm{T}$ cells and also the regulation of cytokines can do with the help of iron, and production of antibodies decreases when iron is deficient [10]. The activity of SARS-CoV and MERS-CoV helicases during replication needs ATP, and ATP synthesis needs iron. Iron homeostasis correlated with hepcidin and expression of hepcidin can influence by some cytokines like IL6 and IL-1B. SARS-CoV-2 causes increasing in IL-1B, IFN- $\gamma$, and IP10 levels and so these cytokines cause increasing of hepcidin and Iron storage in macrophages and hepatocytes will be enhanced. High iron storage in these cells will help viral replication [31]. CQ and HCQ may inhibit the release of IL-6, IL-1B, and TNF-a and so cause a decrease in hepcidin and inhibit viral replication [32]. Also, some drugs like tocilizumab suppress the synthesis of hepcidin [33]. Both host and pathogen need iron, and its deficiency impairs immunity in the host. Although excessive iron increases oxidative stress and risk of mutation in the viral genome [34]. It has been reported that iron leakage is a risk factor for the development of COVIV-19 disease [35]. A high level of iron may increase viral infections. So iron chelators may inhibit viruses and can be used as antiviral materials against SARS-CoV-2. Iron has a role in viral replication, and lack of iron prevents replication of SARS-CoV-2, so iron chelators can be used as treatment. Also, the level of iron elevated in pulmonary fibrosis and iron chelators may inhibit pulmonary fibrosis [36]. On the other hand, it has been reported that COVID-19 patients with acute respiratory distress syndrome have low serum levels of Iron and intubation them [37]. The iron concentration $24 \mathrm{mcg} / \mathrm{dl}$ was reported in an 80 -year-old patient with COVID-19 [38].

\section{Potassium}

It has shown that COVID-19 patient's loss of potassium from urine so it causes hypokalemia in these patients. The entrance of the virus decreases the ACE2 and causes a reduction of angiotensin II decay, so the secretion of aldosterone increases, and it causes loss of potassium from urine [39, 40]. Hypokalemia is a high prevalence condition (up to 62\%) among COVID-19 patients. About 108 of 175 patients had less than $3 \mathrm{mmol} / \mathrm{L}$ of $\mathrm{K}^{+}$in plasma, and 10 people had $4 \mathrm{mmol} / \mathrm{L}$ plasma $\mathrm{K}^{+}$. The recommended level of plasma $\mathrm{K}^{+}$ for myocardial patients is $4 \mathrm{mmol} / \mathrm{L}$. The normal amount of plasma and serum potassium is 4 to 5.5 and 4.5 to 5.5 . There are few reports about serum level of $\mathrm{K}^{+}$, and only in one study reported 4.6 in the ICU patients and 4.1 in the non-ICU patients. The severity of COVID-19 illness is relevant to the amount of potassium deficiency. Myocardial failure can be prevented by an adequate amount of plasma $\mathrm{K}^{+}$. SARSCoV-2 can hurt the heart through ACE2s, so it is good to control the potassium levels. Increasing gastrointestinal and urinary loss of $\mathrm{K}^{+}$are both causes of hypokalemia in COVID-19 patients, but the gastrointestinal loss has less effect than urinary loss [41].

\section{Sodium}

The most common impairments of electrolyte balance in patients are hyponatremia that mostly due to the syndrome of inappropriate antidiuresis (SIAD) [42]. The sodium in the serum of patients with pneumonia infected by SARS-CoV-2 is lower than non-pneumonia patients [43]. COVID-19 pathology is associated with IL-6, and this cytokine causes electrolyte disorder by inducing the vasopressin non-osmotic release. It has observed that IL-6 reversely correlates with $\left[\mathrm{Na}^{+}\right]$and straightly associates with the $\mathrm{PaO}_{2} / \mathrm{FiO}_{2}(\mathrm{P} / \mathrm{F})$ ratio. $\left[\mathrm{Na}^{+}\right]$and $\mathrm{P} / \mathrm{F}$ ratios were significantly lower in patients with a higher level of IL-6 [42]. Sodium level was low at $123 \mathrm{mmol} / \mathrm{l}$ in a 77-year-old man with positive RT-PCR for COVID-19. There is not any other cause for hyponatremia in this case. Also, it has been reported that up to $12 \%$ of coronavirus patients have a low sodium level [44]. Expression of ACE2s in kidneys is higher than the lungs, and kidneys are a strong target for SARS-CoV-2. It has been reported that increases in sodium intake cause downregulation in ACE2 and by reduction of ACE2s, entry of coronavirus into cells also decreases. And sodium deficiency may increase the risk of developing severe and virulent COVID-19 infection [45, 46].

\section{Calcium}

Coronavirus membrane fusion is associated with extracellular conditions. It has been observed that cellular ion conditions involve in the entrance of the virus [47]. The fusion of SARS$\mathrm{CoV}$ and MERS-CoV into cells was influenced by $\mathrm{Ca}^{+}$[48], and it has demonstrated that their entry into some cell lines decreased when intracellular calcium is chelated [49]. SARS$\mathrm{CoV}$ infection reduces more than MERS-CoV because SARS-CoV fusion peptide binds with two $\mathrm{Ca}^{2+}$ ions but MERS-CoV binds one [50].

\section{Magnesium}

The role of magnesium in immune function is mediated by several mechanisms including immune cell adherence, antibody-dependent cytolysis, and immunoglobulin M (IgM) lymphocyte binding, exerting a significant effect on the immunoglobulin synthesis, macrophage response to lymphokines, and $\mathrm{T}$ helper-B cell adherence $[23,51]$. 


\section{Folic Acid}

A 3CL hydrolase (also called the main protease) has an important role in the coronavirus life cycle. It has shown that folic acid molecules create hydrogen bonds with this enzyme and inhibit its activity, so it can impair the viral life cycle. As folic acid has an inhibitory function, it might be useful for the treatment of new coronavirus [52].

\section{Copper}

Copper is an essential trace element in the body and the need for protecting DNA from oxidative stress [53]. $7.8 \mathrm{mg} /$ day intake of copper has seen that causes increase ceruloplasmin activity, benzylamine oxidase, and superoxide dismutase compares to $1.6 \mathrm{mg} /$ day. Although it has seen that amount of neutrophil, serum IL-2R, and the antibody titer against the Beijing strain of influenza reduce by higher intake of copper $(7.8 \mathrm{mg} /$ day) $[23,54]$. Impairment of the immune system and enhanced rate of infections has been associated with copper deficiency [55]. Chronic TNF-a induced inflammation of the lungs may cause by a lack of copper [56]. Although the excessive level of copper in serum has adverse effects on human respiratory health [57]. There is no suggestion for the amount of copper intake against COVID-19, and also it is unknown that the changes due to copper are beneficial or not [13]. But it has reported that RNA replication of COVID-19 can inhibit by copper, RDV (an analog of nucleotide for treatment of Ebola), and NO (nitric oxide) together [58]. It has been reported that the human immune system response is weak when $\mathrm{Cu}$ is deficient. The level of serum copper in COVID-19 patients is unknown. The entry of the virus and its replication inhibit by $\mathrm{Cu}^{+}$ions and $\mathrm{Cu}$ oxide nanoparticles. Also, they impair viral mRNA and capsid proteins. Therefore, $\mathrm{Cu}$ supplements may affect the host immune system and may be beneficial for patients with COVID-19 illness. It is evident that copper and zinc are competitively absorbed in the gastrointestinal tract. So zinc intake of high doses (>150 mg/day) can result in $\mathrm{Cu}$ deficiency in healthy individuals. So people who are using zinc supplements regularly may be at risk of severing SARS-CoV-2 because of malabsorption of $\mathrm{Cu}$ from jejunum [59]. Also, high intake of copper may have some adverse effects including gastrointestinal symptoms (cramps, abdominal pain, nausea, diarrhea, and vomiting) and kidney and liver toxicity resulting to coma [58].

Table 1 Summary of the electrolytes and trace element roles in the COVID-19

\begin{tabular}{|c|c|c|}
\hline Element & Physiologic role & Role in COVID-19 \\
\hline Zinc & $\begin{array}{l}\text { It has a role in both innate and adaptive immune systems } \\
\text { and also has an antiviral activity [16] }\end{array}$ & $\begin{array}{l}\text { Zinc inhibits the activity of RNA-dependent RNA poly- } \\
\text { merase (RdRp) of coronavirus [18], and compound both } \\
\text { of zinc and CQ/HCQ is useful for COVID-19 treatment } \\
{[19]}\end{array}$ \\
\hline Selenium & $\begin{array}{l}\text { Selenium is a free radical scavenger and helps cellular } \\
\text { immunity [24] }\end{array}$ & $\begin{array}{l}\text { High selenium intake }(50-100 \mu \mathrm{g} / \text { day }) \text { causes better and } \\
\text { more immune responses [29] }\end{array}$ \\
\hline Iron & $\begin{array}{l}\text { Iron is needed for some reactions and cellular functions } \\
\text { like RNA/DNA synthesis and repairs [10] }\end{array}$ & $\begin{array}{l}\text { High level of iron may increase viral infections [36], } \\
\text { although it has reported that COVID-19 patients have } \\
\text { low serum level of iron [37] }\end{array}$ \\
\hline Potassium & $\begin{array}{l}\text { It is important for cell functions and the need for membrane } \\
\text { potential [61] }\end{array}$ & $\begin{array}{l}\text { Hypokalemia is a high prevalence condition (up to } 62 \% \text { ) } \\
\text { among COVID-19 patients [41] }\end{array}$ \\
\hline Sodium & Sodium can modulate immune cell activities [62] & $\begin{array}{l}\text { The sodium in the serum of patients with pneumonia } \\
\text { infected by SARS-CoV-2 is lower than non-pneumonia } \\
\text { patients [43] }\end{array}$ \\
\hline Calcium & Calcium has a role in the activation of lymphocytes [63] & $\begin{array}{l}\text { It has seen that SARS-CoV entry into some cell lines de- } \\
\text { creases when intracellular calcium decreases [49] }\end{array}$ \\
\hline Magnesium & $\begin{array}{l}\text { It has important roles in immune functions including } \\
\text { immunoglobulin synthesis and immunoglobulin M } \\
\text { (IgM) lymphocyte binding [51] }\end{array}$ & ND \\
\hline Folic acid & $\begin{array}{l}\text { Synthesis of purines and thymidylate that they are } \\
\text { necessary for mitochondrial producing of ATP need } \\
\text { folic acid [65] }\end{array}$ & $\begin{array}{l}\text { Folic acid impairs the viral life cycle by creating hydrogen } \\
\text { binds with 3CL hydrolase. In severe patients, the level of } \\
\text { folic acid is lower }[52,64]\end{array}$ \\
\hline Copper & $\begin{array}{l}\text { It is an essential trace element in body and is needed for } \\
\text { protecting DNA from oxidative stress [53] }\end{array}$ & $\begin{array}{l}\text { It has been reported that the human immune system } \\
\text { response was weak when } \mathrm{Cu} \text { is deficient. The level of } \\
\text { serum copper in COVID-19 patients is unknown[59] }\end{array}$ \\
\hline
\end{tabular}




\section{Discussion}

A new widespread viral pneumonia is due to the new coronavirus (SARS-CoV2). There is not enough information about this virus and its disease. There is no special drug or vaccine for this virus yet. Many parameters and body conditions may affect the entrance and pathogenicity of coronavirus in the human body. Also, environmental circumstances may have affected the trace elements level in the body; for example, heavy metals and volcanic gases and trace elements present in the air pollution along with specific climate conditions and regional topography may be involved in the spread of COVID-19 pandemic [60].

One major parameter is electrolyte balance and sufficient intake of minerals and vitamins because they affect the immune system. Impairment in electrolyte balances and lack of trace elements or vitamins cause immune system dysfunction and increase the risk of severe infection [7]. Here, we studied all the researches about electrolyte changes in COVID-19 until now. We have understood that some electrolyte changes and increasing or decreasing some of them can affect on pathogenicity of SARS-CoV2. And also some changes in electrolytes or trace elements are due to SARS-CoV2. Some changes might have a good effect on patients and cause improvement in the disease. Increasing zinc is good because zinc has an antiviral effect and a combination of zinc and CQ/HCQ may have more effect due to ionophore function of CQ/HCQ for zinc $[19,20]$. But increasing in iron may have a bad effect because of excessive iron increase oxidative stress and also iron has a role in the replication of SARS-CoV2. So decreasing iron by using iron chelators can be considered a treatment $[34,36]$. Also, both hypokalemia and hyponatremia were reported in COVID-19 patients, and deficiency of both sodium and potassium is dangerous for the body [41, 43]. Selenium deficiency causes immune system dysfunction and increases the viral replication [28]; copper might be beneficial for COVID-19 patients due to inhibitory effects on entry and impairment of viral mRNA and capsid [59], calcium decreases the entrance of viruses [49], and folic acid may impair the viral life cycle [52]. Finally, we suggest controlling the level of electrolytes and the number of trace elements in the body and using supplements if needed to make treatments better and faster (All data were summarized in Table 1).

\section{Conclusion}

In the present study, by reviewing the available articles on the level of serum electrolytes and micronutrients in patients with COVID-19, significant results were obtained, and it was found that the trace elements and electrolytes levels in the blood circulation have important roles to alleviate or increase the severity of the disease and thus the mortality rates of the patients are affected. Therefore, personalized medicine via measuring the level of the trace elements and electrolytes in patients with COVID-19 and supporting the deficiencies as soon as possible to return the body to a physiologic condition to choose the accurate treatment, shorten hospitalization time, and faster recovery is suggested.

Authors' Contributions The conception and design of the study: F.N. and M.T. Acquisition of data, analysis, and interpretation of data: A.B. and F.N. Drafting the article: A.B. and F.N. Revising the article critically for important intellectual content: M.T., P.H., and F.N. Final approval of the version to be submitted: M.T. and F.N.

Funding This work was supported financially by Hamadan University of Medical Sciences, Hamadan, Iran.

Data Availability All data are available via the corresponding author.

\section{Compliance with Ethical Standards}

Conflict of Interest The authors declare that they have no conflict of interest.

Code Availability Not applicable.

\section{References}

1. Nishiga M, Wang DW, Han Y, Lewis DB, Wu JC (2020) COVID19 and cardiovascular disease: from basic mechanisms to clinical perspectives. Nat Rev Cardiol:1-16

2. Butler MJ, Barrientos RM (2020) The impact of nutrition on COVID-19 susceptibility and long-term consequences. Brain Behav Immun

3. Yaqoob P (2016) Ageing alters the impact of nutrition on immune function. Proc Nutr Soc 76:1-5. https://doi.org/10.1017/ S0029665116000781

4. D'Amico F, Baumgart DC, Danese S, Peyrin-Biroulet L (2020) Diarrhea during COVID-19 infection: pathogenesis, epidemiology, prevention and management. Clin Gastroenterol Hepatol 18:16631672

5. Caccialanza R, Laviano A, Lobascio F, Montagna E, Bruno R, Ludovisi S, Corsico AG, Di Sabatino A, Belliato M, Calvi M, Iacona I, Grugnetti G, Bonadeo E, Muzzi A, Cereda E (2020) Early nutritional supplementation in non-critically ill patients hospitalized for the 2019 novel coronavirus disease (COVID-19): rationale and feasibility of a shared pragmatic protocol. Nutrition (Burbank, Los Angeles County, Calif) 74:110835. https://doi.org/ 10.1016/j.nut.2020.110835

6. Zhang L, Liu Y (2020) Potential interventions for novel coronavirus in China: a systematic review. J Med Virol 92(5):479-490. https://doi.org/10.1002/jmv.25707

7. Chandra RK (1997) Nutrition and the immune system: an introduction. Am J Clin Nutr 66(2):460s-463s. https://doi.org/10.1093/ ajcn/66.2.460S

8. Gombart AF, Pierre A, Maggini S (2020) A review of micronutrients and the immune system-working in harmony to reduce the risk of infection. Nutrients 12(1):236. https://doi.org/ 10.3390/nu12010236

9. Calder PC, Carr AC, Gombart AF, Eggersdorfer M (2020) Optimal nutritional status for a well-functioning immune system is an 
important factor to protect against viral infections. Nutrients 12(4). https://doi.org/10.3390/nu12041181

10. Iddir M, Brito A, Dingeo G, Fernandez Del Campo SS, Samouda H, La Frano MR, Bohn T (2020) Strengthening the immune system and reducing inflammation and oxidative stress through diet and nutrition: considerations during the COVID-19 crisis. Nutrients 12(6). https://doi.org/10.3390/nu12061562

11. Rahman MT, Idid SZ (2020) Can Zn be a critical element in COVID-19 treatment? Biol Trace Elem Res. https://doi.org/10. 1007/s12011-020-02194-9

12. Wei Z, Burwinkel M, Palissa C, Ephraim E, Schmidt MF (2012) Antiviral activity of zinc salts against transmissible gastroenteritis virus in vitro. Vet Microbiol 160(3-4):468-472. https://doi.org/10. 1016/j.vetmic.2012.06.019

13. Zabetakis I, Lordan R, Norton C, Tsoupras A (2020) COVID-19: the inflammation link and the role of nutrition in potential mitigation. Nutrients 12(5). https://doi.org/10.3390/nu12051466

14. Adams KK, Baker WL, Sobieraj DM (2020) Myth busters: dietary supplements and COVID-19. Ann Pharmacother 54:820-826. https://doi.org/10.1177/1060028020928052

15. Gammoh NZ, Rink L (2017) Zinc in Infection and Inflammation. Nutrients 9(6):624. https://doi.org/10.3390/nu9060624

16. Maares M, Haase H (2016) Zinc and immunity: an essential interrelation. Arch Biochem Biophys 611:58-65. https://doi.org/10. 1016/j.abb.2016.03.022

17. Shittu MO, Afolami OI (2020) Improving the efficacy of chloroquine and hydroxychloroquine against SARS-CoV-2 may require zinc additives - a better synergy for future COVID-19 clinical trials. Infez Med 28(2):192-197

18. Razzaque MS (2020) COVID-19 pandemic: can maintaining optimal zinc balance enhance host resistance? Tohoku J Exp Med 251(3):175-181. https://doi.org/10.1620/tjem.251.175

19. Derwand R, Scholz M (2020) Does zinc supplementation enhance the clinical efficacy of chloroquine/hydroxychloroquine to win todays battle against COVID-19? Med Hypotheses 142:109815. https://doi.org/10.1016/j.mehy.2020.109815

20. Skalny AV, Rink L, Ajsuvakova OP, Aschner M, Gritsenko VA, Alekseenko SI, Svistunov AA, Petrakis D, Spandidos DA, Aaseth J, Tsatsakis A, Tinkov AA (2020) Zinc and respiratory tract infections: perspectives for COVID-19 (review). Int J Mol Med. https:// doi.org/10.3892/ijmm.2020.4575

21. Theodore Coroneo M (2020) The eye as the discrete but defensible portal of coronavirus infection. Ocul Surf. https://doi.org/10.1016/j. jtos.2020.05.011

22. Iovino L, Mazziotta F, Carulli G, Guerrini F, Morganti R, Mazzotti V, Maggi F, Macera L, Orciuolo E, Buda G, Benedetti E, Caracciolo F, Galimberti S, Pistello M, Petrini M (2018) Highdose zinc oral supplementation after stem cell transplantation causes an increase of TRECs and CD4+ naïve lymphocytes and prevents TTV reactivation. Leuk Res 70:20-24. https://doi.org/10. 1016/j.leukres.2018.04.016

23. Jayawardena R, Sooriyaarachchi P, Chourdakis M, Jeewandara C, Ranasinghe P (2020) Enhancing immunity in viral infections, with special emphasis on COVID-19: a review. Diabetes Metab Syndr Clin Res Rev 14(4):367-382. https://doi.org/10.1016/j.dsx.2020. 04.015

24. Jamaati H, Dastan F, Tabarsi P, Marjani M, Saffaei A, Hashemian SM (2020) A fourteen-day experience with coronavirus disease 2019 (COVID-19) induced acute respiratory distress syndrome (ARDS): an Iranian treatment protocol. Iran J Pharm Res 19(1): 31-36. https://doi.org/10.22037/ijpr.2020.113337.14239

25. Guillin OM, Vindry C, Ohlmann T, Chavatte L (2019) Selenium, selenoproteins and viral infection. Nutrients 11(9). https://doi.org/ 10.3390/nu11092101

26. Harthill M (2011) Review: micronutrient selenium deficiency influences evolution of some viral infectious diseases. Biol Trace
Elem Res 143(3):1325-1336. https://doi.org/10.1007/s12011-0118977-1

27. Ma X, Bi S, Wang Y, Chi X, Hu S (2019) Combined adjuvant effect of ginseng stem-leaf saponins and selenium on immune responses to a live bivalent vaccine of Newcastle disease virus and infectious bronchitis virus in chickens. Poult Sci 98(9):3548-3556. https://doi.org/10.3382/ps/pez207

28. Zhang J, Taylor EW, Bennett K, Saad R, Rayman MP (2020) Association between regional selenium status and reported outcome of COVID-19 cases in China. Am J Clin Nutr 111:12971299. https://doi.org/10.1093/ajcn/nqaa095

29. Broome CS, McArdle F, Kyle JA, Andrews F, Lowe NM, Hart CA, Arthur JR, Jackson MJ (2004) An increase in selenium intake improves immune function and poliovirus handling in adults with marginal selenium status. Am J Clin Nutr 80(1):154-162. https:// doi.org/10.1093/ajen/80.1.154

30. Ivory K, Prieto E, Spinks C, Armah CN, Goldson AJ, Dainty JR, Nicoletti C (2017) Selenium supplementation has beneficial and detrimental effects on immunity to influenza vaccine in older adults. Clin Nutr 36(2):407-415. https://doi.org/10.1016/j.clnu.2015.12. 003

31. Liu W, Zhang S, Nekhai S, Liu S (2020) Depriving Iron supply to the virus represents a promising adjuvant therapeutic against viral survival. Curr Clin Microbiol Rep 7:13-19. https://doi.org/10.1007/ s40588-020-00140-w

32. Quiros Roldan E, Biasiotto G, Magro P, Zanella I (2020) The possible mechanisms of action of 4-aminoquinolines (chloroquine/ hydroxychloroquine) against Sars-Cov-2 infection (COVID-19): a role for iron homeostasis? Pharmacol Res 158:104904. https://doi. org/10.1016/j.phrs.2020.104904

33. Shah A, Frost JN, Aaron L, Donovan K, Drakesmith H (2020) Systemic hypoferremia and severity of hypoxemic respiratory failure in COVID-19. Crit Care (London, England) 24(1):320. https:// doi.org/10.1186/s13054-020-03051-w

34. Wessling-Resnick M (2018) Crossing the Iron gate: why and how transferrin receptors mediate viral entry. Annu Rev Nutr 38:431458. https://doi.org/10.1146/annurev-nutr-082117-051749

35. Jayaweera J, Reyes M, Joseph A (2019) Childhood iron deficiency anemia leads to recurrent respiratory tract infections and gastroenteritis. Sci Rep 9(1):12637. https://doi.org/10.1038/s41598-01949122-z

36. Dalamaga M, Karampela I, Mantzoros CS (2020) Commentary: could iron chelators prove to be useful as an adjunct to COVID19 treatment regimens? Metab Clin Exp 108:154260. https://doi. org/10.1016/j.metabol.2020.154260

37. Bolondi G, Russo E, Gamberini E, Circelli A, Meca MCC, Brogi E, Viola L, Bissoni L, Poletti V, Agnoletti V (2020) Iron metabolism and lymphocyte characterisation during Covid-19 infection in ICU patients: an observational cohort study. World J Emerg Surg 15(1): 41. https://doi.org/10.1186/s13017-020-00323-2

38. Hadadi A, Mortezazadeh M, Kolahdouzan K, Alavian G (2020) Does recombinant human erythropoietin administration in critically ill COVID-19 patients have miraculous therapeutic effects? J Med Virol 92:915-918. https://doi.org/10.1002/jmv.25839

39. Pal R, Bhansali A (2020) COVID-19, diabetes mellitus and ACE2: the conundrum. Diabetes Res Clin Pract 162:108132. https://doi. org/10.1016/j.diabres.2020.108132

40. Lippi G, South AM, Henry BM (2020) Electrolyte imbalances in patients with severe coronavirus disease 2019 (COVID-19). Ann Clin Biochem 57(3):262-265. https://doi.org/10.1177/ 0004563220922255

41. Chen D, Li X, Song Q, Hu C, Su F, Dai J (2020) Hypokalemia and clinical implications in patients with coronavirus disease 2019 (COVID-19). https://doi.org/10.1101/2020.02.27.20028530

42. Berni A, Malandrino D, Parenti G, Maggi M, Poggesi L, Peri A (2020) Hyponatremia, IL-6, and SARS-CoV-2 (COVID-19) 
infection: may all fit together? J Endocrinol Investig 43:1137-1139. https://doi.org/10.1007/s40618-020-01301-w

43. Zhang XL, Cai H, Hu JH, Lian JS, Gu JQ, Zhang SY, Ye CY, Lu YF, Jin CL, Yu GD, Jia HY, Zhang YM, Sheng JF, Li LJ, Yang YD (2020) Epidemiological, clinical characteristics of cases of SARS$\mathrm{CoV}-2$ infection with abnormal imaging findings. Int $\mathrm{J}$ Infect Dis 94:81-87. https://doi.org/10.1016/j.ijid.2020.03.040

44. Butt I, Sawlani V, Geberhiwot T (2020) Prolonged confusional state as first manifestation of COVID-19. Ann Clin Transl Neurol 7:1450-1452. https://doi.org/10.1002/acn3.51067

45. Post A, Dullaart RPF, Bakker SJL (2020) Is low sodium intake a risk factor for severe and fatal COVID-19 infection? Eur J Intern Med 75:109. https://doi.org/10.1016/j.ejim.2020.04.003

46. Post A, Dullaart RPF, Bakker SJL (2020) Sodium status and kidney involvement during COVID-19 infection. Virus Res 286:198034. https://doi.org/10.1016/j.virusres.2020.198034

47. Martens S, McMahon HT (2008) Mechanisms of membrane fusion: disparate players and common principles. Nat Rev Mol Cell Biol 9(7):543-556. https://doi.org/10.1038/nrm2417

48. Dubé M, Rey FA, Kielian M (2014) Rubella virus: first calciumrequiring viral fusion protein. PLoS Pathog 10(12):e1004530 e1004530. https://doi.org/10.1371/journal.ppat.1004530

49. Lai AL, Millet JK, Daniel S, Freed JH, Whittaker GR (2017) The SARS-CoV fusion peptide forms an extended bipartite fusion platform that perturbs membrane order in a calcium-dependent manner. J Mol Biol 429(24):3875-3892. https://doi.org/10.1016/j.jmb. 2017.10.017

50. Tang T, Bidon M, Jaimes JA, Whittaker GR, Daniel S (2020) Coronavirus membrane fusion mechanism offers a potential target for antiviral development. Antivir Res 178:104792. https://doi.org/ 10.1016/j.antiviral.2020.104792

51. Liang RY, Wu W, Huang J, Jiang SP, Lin Y (2012) Magnesium affects the cytokine secretion of $\mathrm{CD}^{+} \mathrm{T}$ lymphocytes in acute asthma. J Asthma 49(10):1012-1015. https://doi.org/10.3109/ 02770903.2012.739240

52. Serseg T, Benarous K, Yousfi M (2020) Hispidin and Lepidine E: two natural compounds and folic acid as potential inhibitors of 2019-novel coronavirus main protease (2019-nCoVMpro), molecular docking and SAR study. Curr Comput Aided Drug Des 16. https://doi.org/10.2174/1573409916666200422075440

53. Uriu-Adams JY, Keen CL (2005) Copper, oxidative stress, and human health. Mol Asp Med 26(4):268-298. https://doi.org/10. 1016/j.mam.2005.07.015

54. Turnlund JR, Jacob RA, Keen CL, Strain JJ, Kelley DS, Domek JM, Keyes WR, Ensunsa JL, Lykkesfeldt J, Coulter J (2004) Longterm high copper intake: effects on indexes of copper status, antioxidant status, and immune function in young men. Am J Clin Nutr 79(6):1037-1044. https://doi.org/10.1093/ajcn/79.6.1037

55. Bonham M, O'Connor JM, Hannigan BM, Strain JJ (2002) The immune system as a physiological indicator of marginal copper status? Br J Nutr 87(5):393-403. https://doi.org/10.1079/ bjnbjn2002558

56. Liu L, Geng X, McDermott J, Shen J, Corbin C, Xuan S, Kim J, Zuo L, Liu Z (2016) Copper deficiency in the lungs of TNF- $\alpha$ transgenic mice. Front Physiol 7:234-234. https://doi.org/10. 3389/fphys.2016.00234

57. Pearson P, Britton J, McKeever T, Lewis SA, Weiss S, Pavord I, Fogarty A (2005) Lung function and blood levels of copper, selenium, vitamin $\mathrm{C}$ and vitamin $\mathrm{E}$ in the general population. Eur J Clin Nutr 59(9):1043-1048. https://doi.org/10.1038/sj.ejcn.1602209

58. Andreou A, Trantza S, Filippou D, Sipsas N, Tsiodras S (2020) COVID-19: the potential role of copper and $\mathrm{N}$-acetylcysteine (NAC) in a combination of candidate antiviral treatments against SARS-CoV-2. In vivo (Athens, Greece) 34(3 Suppl):1567-1588. https://doi.org/10.21873/invivo.11946

59. Raha S, Mallick R, Basak S, Duttaroy AK (2020) Is copper beneficial for COVID-19 patients? Med Hypotheses 142:109814. https://doi.org/10.1016/j.mehy.2020.109814

60. Raciti L, Calabrò RS (2020) Can volcanic trace elements facilitate Covid-19 diffusion? A hypothesis stemming from the Mount Etna area, Sicily. Med Hypotheses: 110058

61. Palmer BF, Clegg DJ (2016) Physiology and pathophysiology of potassium homeostasis. Adv Physiol Educ 40(4):480-490. https:// doi.org/10.1152/advan.00121.2016

62. Wilck N, Balogh A, Markó L, Bartolomaeus H, Müller DN (2019) The role of sodium in modulating immune cell function. Nat Rev Nephrol 15(9):546-558. https://doi.org/10.1038/s41581-019-0167$\mathrm{y}$

63. Feske S (2007) Calcium signalling in lymphocyte activation and disease. Nat Rev Immunol 7(9):690-702. https://doi.org/10.1038/ nri2 152

64. Itelman E, Wasserstrum Y, Segev A, Avaky C, Negru L, Cohen D, Turpashvili N, Anani S, Zilber E, Lasman N, Athamna A, Segal O, Halevy T, Sabiner Y, Donin Y, Abraham L, Berdugo E, Zarka A, Greidinger D, Agbaria M, Kitany N, Katorza E, Shenhav-Saltzman G, Segal G (2020) Clinical characterization of 162 COVID-19 patients in Israel: preliminary report from a large tertiary center. Israel Med Assoc J 22(5):271-274

65. Henry CJ, Nemkov T, Casás-Selves M, Bilousova G, Zaberezhnyy V, Higa KC, Serkova NJ, Hansen KC, D'Alessandro A, DeGregori J (2017) Folate dietary insufficiency and folic acid supplementation similarly impair metabolism and compromise hematopoiesis. Haematologica 102(12):1985-1994. https://doi.org/10.3324/ haematol.2017.171074

Publisher's Note Springer Nature remains neutral with regard to jurisdictional claims in published maps and institutional affiliations. 